\title{
Associations between TaqI Polymorphisms in Vitamin D Receptor Gene and Type 2 Diabetes Mellitus in Obese Iraqi Population
}

\section{Saifuldeen Z AL-Darraji ${ }^{1}$, Hassan F AL-Azzawie ${ }^{{ }^{*}}$ and Abbas M AL-Kharsani ${ }^{2}$}

${ }^{1}$ Department of Biotechnology, College of Science, Baghdad University, Iraq

2Iraqi National Diabetic Center, College of Medicine, Al-Mustansiryia University, Iraq

\begin{abstract}
To assess the impact of the association of VDR Taql polymorphism with T2 diabetic mellitus in Iraqi patients, a total of 200 T2DM diabetic were enrolled in this study. Polymerase chain reaction-restriction fragment length polymorphism was used to test the genotype and allele frequency of Taql (rs731236). Results showed that Patients with T allele (TT or Tt) was significantly associated with higher risk of diabetic disease $39 \%, 78 / 200,47.5 \%, 95 / 200$; $\mathrm{P}=0.024$ ) compared with patients without $\mathrm{T}$ allele (tt; $13.5 \%, 27 / 200 ; \mathrm{P}=0.003$ ). This association was also significant after adjusting for hemoglobin A1c level, body mass index, age, sex, and diabetes mellitus duration, concurrent dyslipidemia (odds ratio, 2.99; 95\% confidence interval, 1.08 to 8.29; $P=0.035$ ) in logistic regression analysis. Our findings suggest that T allele of Taq1 polymorphism in VDR gene is associated with higher risk of diabetic disease in T2 diabetic Iraqi patients. Taq1 genotype could be used as a susceptibility marker to predict the risk of diabetes complication.
\end{abstract}

Keywords: Diabetic type 2; Polymorphism; VDR; Vitamin D receptor; TaqI

\section{Introduction}

Type 2 diabetes mellitus (T2DM) is a multifactorial disease characterized by insulin resistance and altered insulin secretion and it's influenced by both genetic and environmental factors. In Iraq, the prevalence of T2DM has increased dramatically with the adoption of a new lifestyle of over nutrition and reduced physical activity [1]. T2DM is associated with a high risk of vitamin D deficiency [2]. This deficiency is now considered a public-health because it has been associated with greater risks of other morbidities, such as cardiovascular disease and cancer $[3,4]$. Several studies have shown that vitamin D deficiency might play an important role in the pathogenesis of T2DM. Epidemiological data showed a reduction in vitamin $\mathrm{D}$ deficiency in a London Bangladeshi population at risk for T2DM compared with subjects not at risk [5]. Vitamin D primarily known to be involved in phospho-calcium homeostasis also regulates growth and differentiation of diverse types of cells through specific receptor [6]. Vitamin D and its metabolites could inhibit T-cell proliferation and suppress production of interleukin 1, interleukin 2 , tumor necrosis factor- $\alpha$ and interferon- $\beta[7,8]$. In the nonobese diabetic mouse model for insulin-dependent diabetes mellitus, vitamin $\mathrm{D}$ is necessary for normal insulin release and maintenance of glucose tolerance [9]. Vitamin D is activated after binding to its specific cytosolic/nuclear vitamin D receptor (VDR) [10,11]. VDR is a member of the steroid/thyroid hormone receptor family. The VDR gene as a important candidate gene for T2DM, because vitamin D exerts its effects through the VDR. Genetic alterations of the VDR gene may lead to defects in gene activation or changes in the protein structure of the VDR, both of which could affect the cellular functions of vitamin D. The VDR gene is located on chromosome 12q12-q14, and common polymorphisms have been identified namely BsmI (rs1544410), FokI (rs10735810), TaqI(rs731236 )and ApaI (rs7975232) [12]. The aim of this study was to investigate the association between VDR TaqI(rs731236 gene polymorphisms and T2DM in Iraqi patients against control.

\section{Genotyping and TaqI polymorphism}

The genomic DNA was isolated from peripheral leukocytes obtained from anticoagulant whole blood. Polymerase chain reaction- restriction fragment length polymorphism (PCR-RFLP) was used to determine the Taq1 VDR gene polymorphism. Genotyping for TaqI (rs7975232) was performed with the following primers: Forward 5'CAG AGC ATG GAC AGG GAG CAA-3'. Reverse: 5'-GCA ACT CCT CAT GGC TGA GGT CTC-3'. A 740 bp fragment VDR gene was amplified using the PCR under reactions conditions identical to those used for the FokI polymorphism13. The PCR was conducted in a 25 $\mu \mathrm{L}$ volume, with an initial denaturation of 3 minutes at $94^{\circ} \mathrm{C}$, followed by 30 seconds denaturation at $94^{\circ} \mathrm{C}, 30$ seconds annealing at $62^{\circ} \mathrm{C}$, and 1 minute extension at $72^{\circ} \mathrm{C}$ for 30 cycles, and a final extension of 5 minutes at $72^{\circ} \mathrm{C}$. The PCR products were digested overnight at $37^{\circ} \mathrm{C}$ by Fermentas restriction enzymes, and resolved in 1.5\% agarose gel ethidium bromide by electrophoresis for genotype analysis. Digestion with Taq1 yields 3 genotypes: the wild type homozygote (TT) showed two band (495\&245) bp; heterozygote (Tt) showed four bands $(495,290$, $245,205)$. Homozygote (tt) showed three bands $(290,245,205)$.

\section{Results and Discussion}

Evaluation of the polymorphism within exon 9 of the VDR gene by Taq1 restriction digestion showed that the prevalence of T/T genotype was 78 (39 percent) in T2DM patients and 15 (20 percent) in controls. Results also revealed that the frequency of the T/T genotype was 95 (47.5 percent), and 44 (58.6 percent) in T2DM patients and controls, respectively. The value for the $\mathrm{T}$ allele frequency in T2DM patients was 251 (62.5 percent), and in the control group was 74 (49.3 percent), while the value for the $\mathrm{t}$ allele frequency in T2DM patients was 149

*Corresponding author: AL-Azzawie HF, Department of Biotechnology, College of Science, Baghdad University, Iraq, Tel: 09647712322816; E-mail: hazzawie2@yahoo.com

Received March 16, 2017; Accepted March 30, 2017; Published April 05, 2017

Citation: AL-Darraji SZ, AL-Azzawie HF, AL-Kharsani AM (2017) Associations between Taql Polymorphisms in Vitamin D Receptor Gene and Type 2 Diabetes Mellitus in Obese Iraqi Population. J Diabetes Metab 8: 734. doi: 10.4172/2155-6156.1000734

Copyright: @ 2017 AL-Darraji SZ, et al. This is an open-access article distributed under the terms of the Creative Commons Attribution License, which permits unrestricted use, distribution, and reproduction in any medium, provided the original author and source are credited. 
(37.5 percent), and in the control group was 76 (50.6 percent). Results of this study demonstrated that the genotype and allele differences were significant in T2DM diabetic groups in comparison to the control group $(\mathrm{p}=0.0034$ and $\mathrm{p}=0.0046)$.

A significant association between the presence of the VDR TaqI $\mathrm{T}$ allele and T2DM was observed, while the VDR TaqI $t$ allele was more frequent among the control individuals. These finding suggest a protective role for the $t$ allele in contrast to the role of $\mathrm{T}$ allele which seems to be a predisposing factor to T2DM in the Iraqi population. In addition, the results seem to reinforce the association of the TT genotype with the susceptibility to the T2DM. On the other hand the result present study did not agree well with an observation that corroborated with a metaanalysis study [13], in which the TT genotype association and the TaqI genotypes and allele non association with T2DM was clearly obtained. Results of this work is inconsistent with Errouagul [14] who observed that the tt allele was associated with T2DM in Morocco population. However, further studies failed to show an association between this polymorphisms and T2DM in a Polish [15] Malecki et al. and an Asian meta-analysis study [16]. On the other hand the Hardy-Weinberg Equilibrium (HWE) equation analysis is performed by calculating the allele frequencies and the resulting expected frequencies of the genotype based on these. If the observed frequencies of genotype are close to the expected genotype frequencies calculated from the observed allele frequencies, then the population is in Hardy-Weinberg Equilibrium and allele combinations are likely to be independent of one another. While testing for Hardy-Weinberg $(\mathrm{H}-\mathrm{W})$ equilibrium revealed that T2DM patients showed a significant variation in the distribution of VDR TaqI genotypes $(\mathrm{P}<0.0001)$ this was observed due to differences between the observed and expected frequencies of $T / T, T / t$ and $t / t$ genotypes. Moreover, significant differences were observed in the control sample, in which they and expected genotype frequencies $(\mathrm{P}<0.001)$ (Table 1$)$.

This study demonstrated that VDR gene polymorphism was associated with susceptibility to T2DM in the Iraqi population, which can be explained by differences in VDR TaqI genotype distributions between T2DM and control subjects. The presence of a correlation between VDR polymorphisms and T2DM associated metabolic parameters, including fasting glucose, glucose intolerance, insulin sensitivity, insulin secretion, and calcitriol levels, has been reported in this work studies (Figures 1 and 2). VDR TaqI polymorphisms and T2DM are closely correlated. In patients with T2DM, VDR tt genotype were significantly lower in patients with T2DM than in control individuals. Carrying the $t$ allele of the TaqI SNP might be protective against vitamin D deficiency: In agree with our results a recent meta-analysis did not find any association of the other three polymorphisms (Bsm1, Apal and Taq1) with an increased T2DM risk in overall and subgroup analysis [17].

\section{Conclusion}

It is evident that vitamin $\mathrm{D}$ deficiency has prevailed in Iraqi population with T2DM. Alterations in vitamin D action could be may affect Insulin-Sensitivity, $\beta$-Cell action or both. Moreover our study documents a correlation between VDR Taq-I gene polymorphisms and susceptibility to T2DM in the Iraqi population. The possible action of

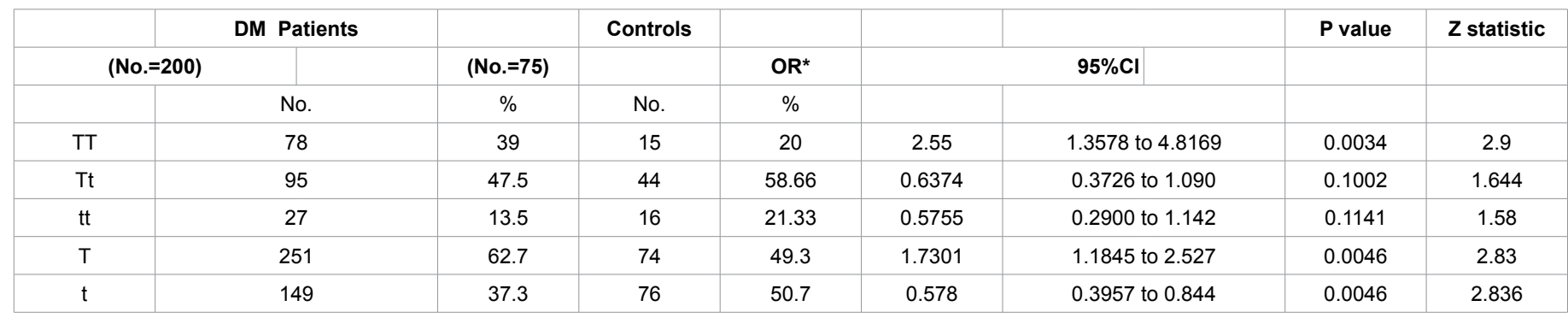

Table 1: Observed numbers and percentage frequencies of VDR genotype and alleles at Taql position in T2DM patients and controls.

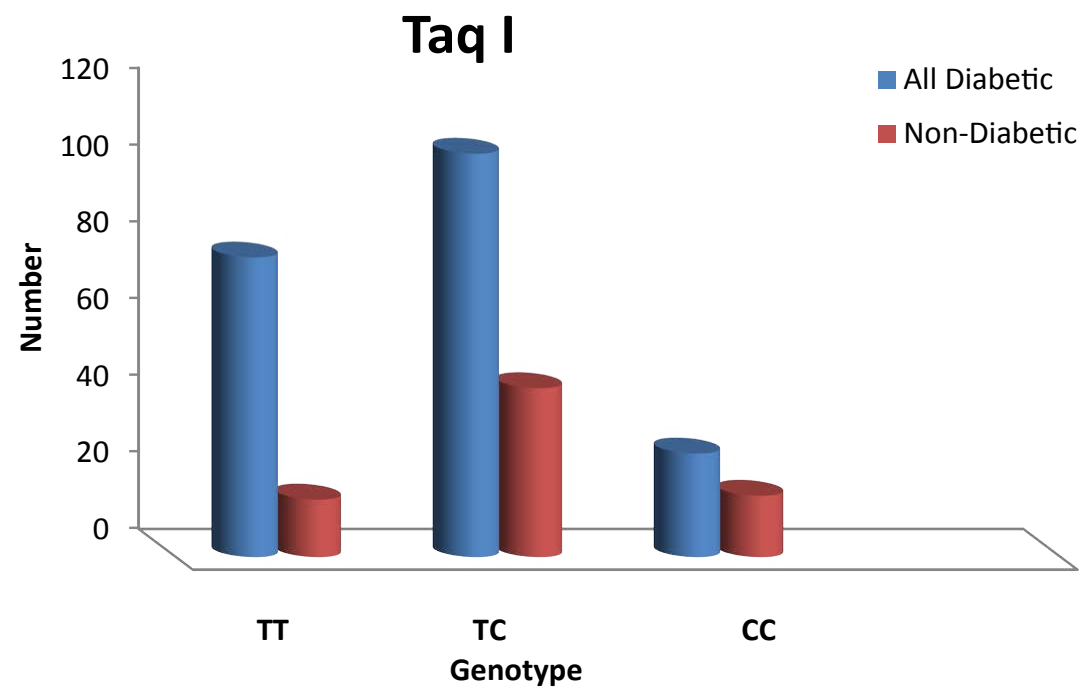

Figure 1: Distribution of the SNP - Taql (rs731236) genotypes of the VDR gene among T2DM Iraqi patients, compared with the non-diabetic control. 
Citation: AL-Darraji SZ, AL-Azzawie HF, AL-Kharsani AM (2017) Associations between Taql Polymorphisms in Vitamin D Receptor Gene and Type 2 Diabetes Mellitus in Obese Iraqi Population. J Diabetes Metab 8: 734. doi: 10.4172/2155-6156.1000734
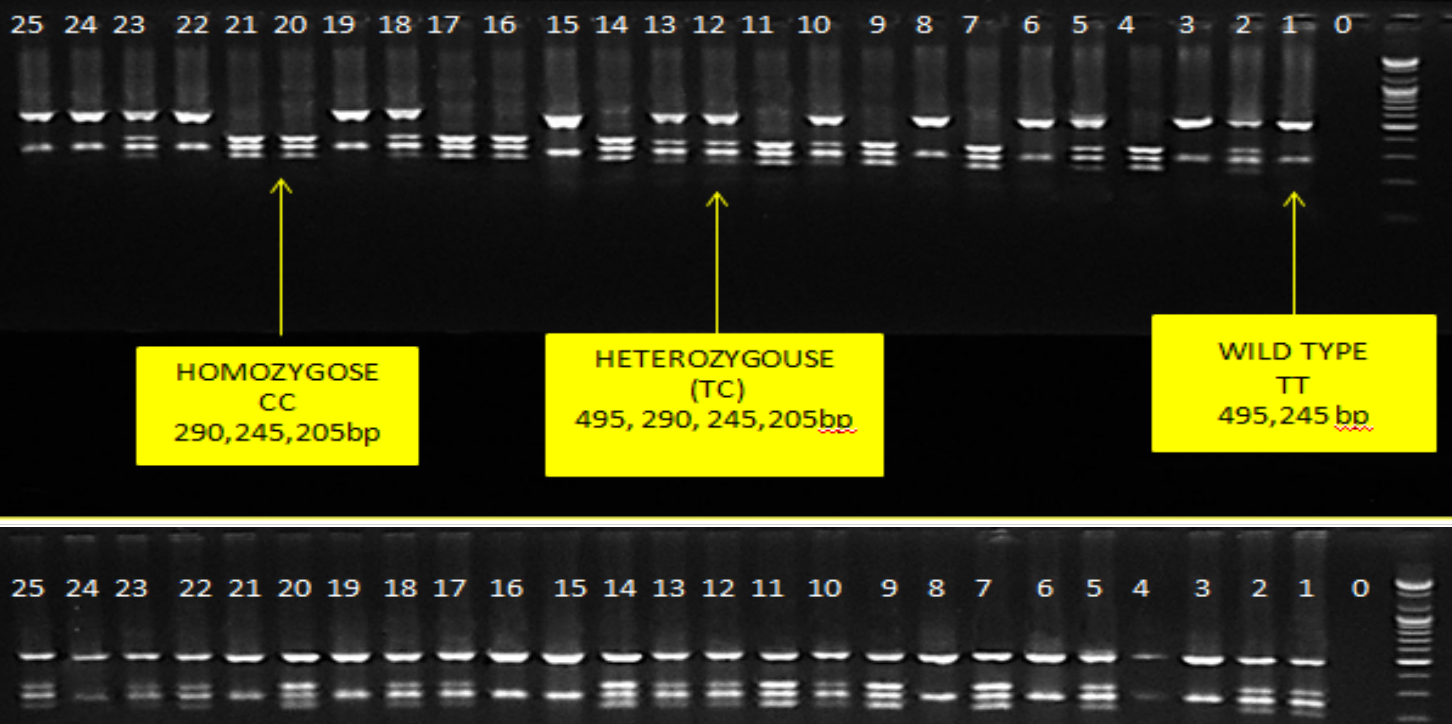

HOMOZYGOSE

$\mathrm{CC}$

$290,245,205 b p$

Have Not been

Founded in

these samples.
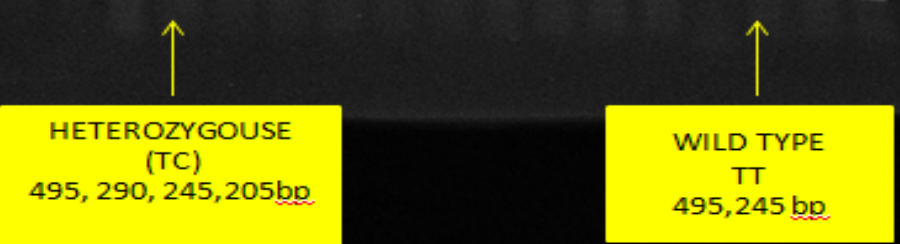

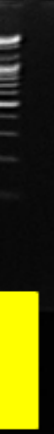

(1)
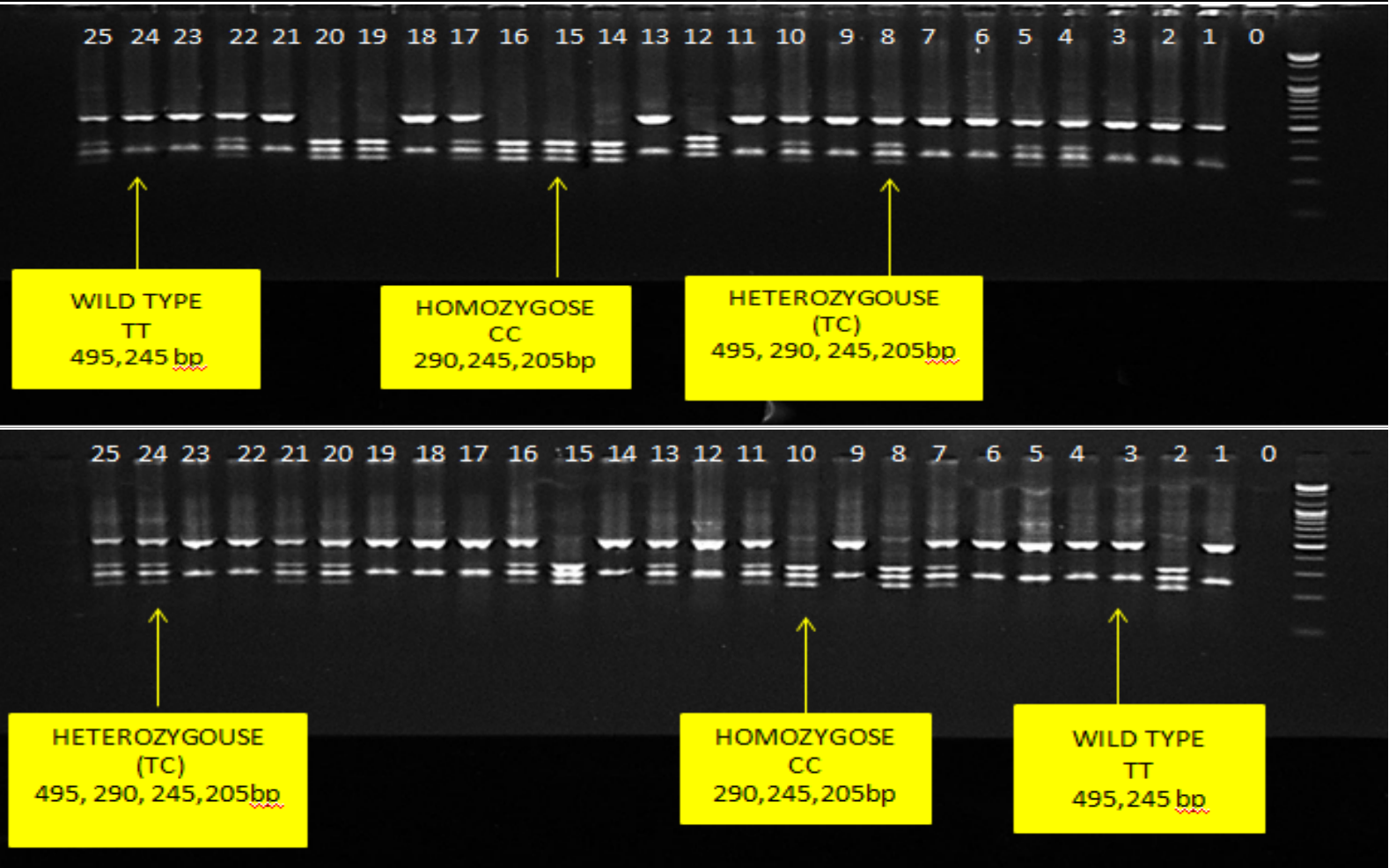

Figure 2: PCR-RFLP analysis of the VDR gene by the Taq1 in the type 2 diabetes mellitus patients and healthy subjects: The wild type homozygote (TT) showed two band $(495 \& 245) \mathrm{bp}$; heterozygote $(\mathrm{Tt})$ showed four bands $(495,290,245,205) \mathrm{bp}$. Homozygote (tt) showed three bands $(290,245,205) \mathrm{bp}$. The product was electrophoresed on 2 percent agarose gel at 90 volt for 1 hour, stained with ethidium bromide, then visualized under U.V light. (A) refers to non-diabetic (B) Diabetic life style (C) Diabetic treated with oral hypoglycemic drug (D) Diabetic treated with Oral drug and insulin injection . M=marker (100-2000bp). 
Citation: AL-Darraji SZ, AL-Azzawie HF, AL-Kharsani AM (2017) Associations between Taql Polymorphisms in Vitamin D Receptor Gene and Type 2 Diabetes Mellitus in Obese Iraqi Population. J Diabetes Metab 8: 734. doi: 10.4172/2155-6156.1000734

vitamin $\mathrm{D}$ in the pathogenesis of T2DM is far from being completely understood. Additionally, further knowledge on this issue may identify new candidate targets in the treatment and prevention of the disease. Therefore, further investigations on this issue are warranted.

\section{Conflict of Interest}

The all authors declare that they have no conflict of interest.

\section{References}

1. Benrahma H, Abidi O, Melouk L, Ajjemami M, Rouba H, et al. (2012) Association of the C677T polymorphism in the human methylenetetrahydrofolate reductase (MTHFR) gene with the genetic predisposition for type 2 diabetes mellitus in a Moroccan population. Genetic Testing and Molecular Biomarkers 16: 383-387.

2. Arabi A, El Rassi R, El-Hajj Fuleihan G (2010) Hypovitaminosis D in developing countries-prevalence, risk factors and outcomes. Nature Reviews Endocrinology 6: $550-561$.

3. Garland CF, Comstock GW, Garland FC, Helsing KJ, Shaw EK, et al. (1989) Serum 25-hydroxyvitamin D and colon cancer: eight-year prospective study. Lancet 2: 1176-1178.

4. Pilz S, Marz W, Wellnitz B, Seelhorst U, Fahrleitner-Pammer A, et al. (2008) Association of vitamin $D$ deficiency with heart failure and sudden cardiac death in a large cross-sectional study of patients referred for coronary angiography. The Journal of Clinical Endocrinology and Metabolism 3: 3927-3935.

5. Hitman GA, Mannan N, McDermott MF, Aganna E, Ogunkolade BW, et al. (1998) Vitamin D receptor gene polymorphisms influence insulin secretion in Bangladeshi Asians. Diabetes 47: 688-690.

6. Jones G, Strugnell SA, DeLuca HF (1998) Current understanding of the molecular actions of vitamin D. Physiological Reviews 78: 1193-1231.

7. Rigby WF, Stacy T, Fanger MW (1984) Inhibition of T lymphocyte mitogenesis by 1,25 dihydroxy vitamin D3 (calcitriol). J Clin Investig 74: 1451-1455.
8. Cantorna MT, Zhu Y, Froicu M, Wittke A (2004) Vitamin D status, 1,25-dihydroxy vitamin D3, and the immune system. The American journal of clinical nutrition 2004, 80(6 Suppl) 21: 1717S-1720S.

9. Mathieu C, Laureys J, Sobis H, Vandeputte M, Waer M, et al. (1992) Dihydroxyvitamin D3 prevents insulitis in NOD mice. Diabetes 41: 1491-1495.

10. Mangelsdorf DJ, Thummel C, Beato M, Herrlich P, Schutz G, et al. (1995) The nuclear receptor superfamily: the second decade Cell 83: 835-839.

11. Sone T, Marx SJ, Liberman UA, Pike JW (1990) A unique point mutation in the human vitamin-D receptor chromosomal gene confers hereditary resistance to 1,25-dihydroxyvitamin D3. Mol Endocrinol 4: 623-631.

12. Zhang J, Li W, Liu J, Wu W, Ouyang $\mathrm{H}$, et al. (2012) Polymorphisms in the vitamin $\mathrm{D}$ receptor gene and type 1 diabetes mellitus risk: an update by metaanalysis. Molecular and Cellular Endocrinology 355: 135-142.

13. Amal MH. Mackawy, Mohammed EH. Badawi (2014) Association of vitamin D and vitamin $\mathrm{D}$ receptor gene polymorphisms with chronic inflammation, insulin resistance and metabolic syndrome components in type 2 diabetic Egyptian patients. Meta Gene 2: 540-556.

14. Abdeltif E, Houda B, Hicham C, Noureddine H, AbdelHamid B, et al. (2014) Relationship between Vitamin D Receptor (VDR) Gene Polymorphisms and susceptibility to Type 2 Diabetes Mellitus in Moroccans population. International Journal of Innovation and Applied Studies 8: 503-514.

15. Malecki MT, Frey J, Moczulski D, Klupa T, Kozek E, (2003) Vitamin D receptor gene polymorphisms and association with type 2 diabetes mellitus in a Polish population. Experimental and clinical endocrinology \& diabetes: official journal, German Society of Endocrinology [and] German Diabetes Association 111: 505-509.

16. Li L, Wu B, Liu JY, Yang LB (2013) Vitamin D receptor gene polymorphisms and type 2 diabetes: a meta-analysis. Arch Med Res 10.

17. Lei Li, Abo Wu, Ji-Yong Bo, Liu Aa, Li-Bo (2013) Vitamin D Receptor Gene Polymorphisms and Type 2 Diabetes: A Meta-analysis. Archives of Medical Research 44: e235-e241. 